\title{
ПОЛУЧЕНИЕ МНОГОСЛОЙНЫХ ЦИАНОАКРИЛАТНЫХ НОСИТЕЛЕЙ ДЛЯ ВНУТРИКЛЕТОЧНОЙ ДОСТАВКИ
}

\author{
И.С. Колесникова', Т.С. Серегина', , А.Р. Сатаева', Е.А. Филимонова', \\ Е.В. Ивановская ${ }^{1}$, А.Л. Лусс', В.А. Дятлов ${ }^{1,3}$
}

\author{
1Российский химико-технологический университет имени Д. И. Менделеева, \\ 125047, Россия, Москва, Миусская площадь, 9. \\ 2ФГБУ «НМИЦ ТО им. Н.Н. Приорова», 127299, Россия, Москва, ул. Приорова, 10. \\ ${ }^{3}$ Институт тонких химических технологий имени М. В. Ломоносова, \\ 119435, Россия, Москва, Малая Пироговская ул., 1, с.5.
}

DOI: 10.19163/MedChemRussia2021-2021-405

E-mail: ira.kolesnikova.00@list.ru

Актуальной задачей в фармакологии является внутриядерная доставка ДНК. Известны три механизма доставки, зависящие от типа и размера носителя. Мицеллы диаметром 20-50 нм проникают в клетку минуя механизмы фаго-и пиноцитоза, однако они не стабильны и могут обмениваться содержимым друг с другом и окружающей средой. Капсулы, размером от 200 нм до нескольких микрон, проникают в клетку по механизмам пино- и фагоцитоза, но это сопровождается образованием фагосом с последующей ферментативной атакой носителя. Многослойные носители с размером 100 нм способны проникать в клетку путем слияния поверхностной мембраны с плазмолеммой, не затрагивая механизмы проникновения.

Данная работа посвящена изучению инкапсулирования ДНК в двуслойные поли-2-цианоакрилатные нанокапсулы для внутриядерной доставки по механизму слияния мембран [1,2]. Капсулы такого типа получали в двухфазной несмешиваемой системе, состоящей из дисперсионной фазы 6\% раствора декстрана и дискретной фазы заряженных и незаряженных полимеров. В качестве материала твердой стенки использовали этил-2-цианоакрилат, для получения оболочки капсулы схожей по строению с плазмолеммой, использовали фософтидилхолин, структурированный холестирином. Размер получаемых нанокапсул определяли методом динамического светорассеяния, он варьировался от 100 до 400 нм, в зависимости от времени полимеризации этилцианоакрилата, температуры и интенсивности теплоотвода [3]. Средняя степень инкапсулирования в разных условиях составляет 95\%.

Таким образом, предложен подход к получению двухслойных нанокорпускулярных носителей, содержащих инкапсулированное ДНК. Такие нанокапсулы способны доставлять в клетку физиологические активные вещества минуя клеточные механизмы проникновения.

\section{Литература}

[1] Dyatlov V.A., Katz G.A. Small diameter nanocapsules, process for their preparation and application thereof. Int. Application No PCT/IE 94/000001, Int. Publication No W094/015590, 1994.

[2] Dyatlov V.A., Maleev V.I. Intermediates for the preparation of poly (2-cyanoacrylates) and application of the poly (2-cyanoacrylates) so prepared. Int. Application No PCT/IE 94/000018, 1994, Int. Publication No W095/026371, 1995.

[3] Rustamov I.R., Dyatlov V.A., Grebeneva T.A., Dyatlov A.V., Zaitsev V.V., Maleev V.I. Polycyanoacrylate porous material for bone tissue substitution // Journal of Material Chemistry B. 2014. - I.2. - P. 4310-4317.

$$
-405-
$$

